RADIUM CONCENTRATION FACTORS AND THEIR USE IN HEALTH AND ENVIRONMENTAL RISK ASSESSIMENT

\author{
Anne F. Meinhold ${ }^{1}$ and Leonard D. Hamilton ${ }^{1}$ \\ ${ }^{1}$ Brookhaven National Laboratory \\ Upton, NY 11972
}

BNL -45035

DE92 007601

\title{
INTRODUCTION
}

Produced waters discharged to coastal and offshore waters can contain high levels of radium (Snavely, 1989). Radium is known to be taken up by aquatic animals, and tends to accumulate in bone, shell and exoskeleton. The potential biological uptake of radium by aquatic animals is of concern for two reasons: (1) the potential lose to aquatic animals from the internal radiation associated with accumulated radium and the potential effects on individual animals, populations and ecosystems; and (2) the potential cancer risk to people associated with the ingestion of radium in food.

The most common approach to estimating the uptake of a radionuclide by aquatic animals for use in health and environmental risk assessments is the concentration factor method. The concentration factor method relates the concentration of a contaminant in an organism to the concentration in the surrounding water. Site specific data are not usually available, and generic, default values are often used in risk assessment studies.

This paper describes the concentration factor method, summarizes some of the variables which may influence the concentration factor for radium, reviews reported concentration factors measured in marine environments and presents concentration factors derived from data collected in a study in coastal Louisiana. The use of generic default values for the concentration factor is also discussed.

\section{THE CONCENTRATION FACTOR METHOD}

Concentration factors are commonly used in dose assessments to estimate the levels of radionuclides in aquatic organisms. The concentration factor $(C F)$ is a function of the concentration in the water or sediment $(C)$ and the equilibrium concentration (on a wet weight basis) in the organism (Q).

$$
C F=Q / C
$$

It is usually assumed that there is a linear relationship between $C$ and $Q$ and that the concentration factor is independent of the concentration in the environment. This assumption, along with the assumption that groups of similar organisms have similar concentration factors for a specific radionuclide, allow the use of generic concentration factors in dose assessment models. These assumptions may not always

This research was performed under the auspices of the United States

Department of Energy under Contract No. DE-AC02-75CH00016 
be justified, and generic factors can only be used in a preliminary assessment as a first order estimate of bioaccumulation. Site and organism specific factors are desirable for such a study, but obtaining them can be difficult and expensive.

\section{VARIABLES AFFECTING THE CONCENTRATION FACTOR FOR RADIUM}

The values reported in the literature for the concentration factor have a considerable range. There are a number of factors which contribute to this variation, and they should be considered when using generic factors in dose assessment modeling. Important influenses on the concentration factor include inter-specific differences, differences between organs, the effects of environmental factors, the extent to which the organism is in equilibrium with its surroundings, the relationship between the concentration factor and the concentration of the radionuclide in the water, and the presence of chemically similar elements. These factors contribute to the variation in reported concentration factors and are discussed below.

\section{Species and Trophic Level Differences}

Radium uptake varies among groups of organisms (fish, molluscs, crustaceans) and among species in a group. Differences in habitat, food preference and position in the food web account for some of the differences in concentration factors noted between species. In general, the concentration factors of radionuclides decrease at higher trophic levels.

Swanson (1983) studied the levels of radionuclides in fish from lakes affected by effluents from a uranium mine and mill. Concentration factors for radium varied among species in the same lake (Table 1). Small bottom-feeding forage fish (troutperch, nine spine stickleback, spottail shiner and lake chub) generally had greater radium levels than the larger species. Cisco, a planktivorous species, accumulated smaller amounts of radium than the bottom-feeding foragers. Among the larger fish (white sucker, lake whitefish and lake trout), radium levels were highest in the bottom feeding white suckers, moderate in the omnivorous lake whitefish, and lowest in the lake trout feeding mainly on cisco. The inter-specific differences in concentration factors suggest that use of a single concentration factor to represent all species in a group may not always be appropriate.

Table 1. Concentration factors for whole fish from Beaverlodge Lake. ${ }^{1}$

\begin{tabular}{lc}
\hline Species & Concentration Factor \\
\hline nine spine stickleback & 387 \\
trout-perch & 1473 \\
cisco & 53 \\
spottail shiner & 986 \\
lake chub & 187 \\
white sucker & 287 \\
lake whitefish & 33 \\
lake trout & 13 \\
\hline
\end{tabular}

TFrom Swanson, iśos. 


\section{Differences Between Organs}

Certain radionuclides preferentially concentrate in particular organs of aquatic organisms. Radium is chemically similar to calcium and concentrates in bone, shell and exoskeleton. Table 2 shows the differences in the concentration factor for radium in various parts of three species of fish from a lake contaminated by effluent from a uranium mill and mine (Swanson, 1983). In all three species, bone accumulated the most radium, flesh the least.

Table 2. Concentration factors for various parts of fish from Beaverlodge Lake. ${ }^{1}$

\begin{tabular}{llc}
\hline Species & Portion & Concentration Factor \\
\hline \multirow{3}{*}{ white sucker } & flesh & 12 \\
& skin & 31 \\
& bone & 1793 \\
& whole & 287 \\
& flesh & 3 \\
lake whitefish & skin & 93 \\
& bone & 360 \\
& whole & 33 \\
lake trout & flesh & 1 \\
& skin & 20 \\
& bone & 100 \\
& whole & 13 \\
\hline
\end{tabular}

${ }^{1}$ from Swanson, 1983.

Table 3 gives concentration factors reported for radium in marine molluscs (Iyengar, 1984). In all cases, the shell accumulated more radium than the soft edible parts of the animal. These studies suggest that concentration factors based on the radium content of the whole organism can overestimate the level of radium in the edible portion.

Table 3. Concentration factors for radium in marine molluscs. ${ }^{1}$

\begin{tabular}{llc}
\hline Species & Portion & Concentration Factor \\
\hline oyster & soft parts & 50 \\
(Ostrea sp.) & shell & 500 \\
green mussel & soft parts & 46 \\
(Perna viridis) & shell & 419 \\
snail & soft parts & 63 \\
(Thais sp.) & shell & 156 \\
snail & soft parts & 44 \\
(Petalla radiate) & shell & 256 \\
\hline
\end{tabular}

$1_{\text {from Iyengar, } 1984}$ 


\section{Equilibrium With Surroundings}

The concentration factor method assumes that the organism is in chemical equilibrium with its surroundings. The time required for equilibrium to be attained depends on the half-life of the radionuclide and the biological half-life of the element in the organism (Till and Meyer, 1983). For fresh water mussels, Jeffree observed that the radium concentration in flesh continued to increase with age in mature animals from a single location (Jeffree, cited in Williams, 1984). 28-day experiments in which radium uptake was induced also failed to reach equilibrium (Jeffree, cited in Williams, 1984). These studies suggest that for situations in which the environmental concentrations change over time, organisms will not reach complete equilibrium with their surroundings. Mobile organisms such as fish may also fail to reach equilibrium.

\section{Major Ion Efrects}

The presence of major ions in solution influences the biological uptake of nonnutrient trace substances because chemically analogous substances compete for uptake and retention by organisms. Radium and calcium are chemically similar, and the amount of calcium available can have an effect on the rate of radium uptake.

De Bortoli and Gaglione (1972) found that for three of four lakes studied in Italy, the concentration of calcium in the water was inversely related to the concentration of radium in fish. Jeffree found that uptake of radium by the fresh water mussel (Velesunio angasi) was suppressed in water containing $5 \mathrm{mg} / \mathrm{l}$ calcium, but not in water containing $0.5 \mathrm{mg} / \mathrm{l}$ calcium (cited in Williams, 1984). Barium is also chemically similar to radium, and was found to reduce the uptake of radium by unicellular algae (Sebesta et al., cited in Williams, 1984).

\section{Other Environmental Factors}

Environmental factors, including temperature, salinity and $\mathrm{pH}$ affect the growth and metabolism of organisms, and consequently the uptake of radium and other radionuclides. Small increases in temperature tend to increase biological activity and the uptake and excretion of radionuclides (Till and Meyer, 1983). In a study of zinc65 uptake by shellfish, Duke et al. (1969) found that the primary factors affecting the concentration factor were salinity and temperature.

\section{Relationship Between Concentration in Water and in Organism}

Most applications of the concentration factor method in dose assessment assume a linear relationship botween $C$ (the concentration of the radionuclide in water) and $Q$ (the concentration of the radionuclide in the organism). This assumption allows use of a single concentration factor $(C F=Q / C)$ over a range of environmental concentrations. Available data suggest that this assumption is not valid for all groups or species of organisms.

Williams (1984) investigated the relationship between $C$ and $Q$ for several groups of organisms. He found a linear relationship for insects and fresh water mussels. The data for fresh water mussels were for a single species (Velesumio angasi), but the animals had not reached equilibrium with the surrounding water (Jeffree, cited in Williams, 1984).

Williams (1984) pooled data from a number of studies to test the linearity of the relationship between $C$ and $Q$ for fish. This analysis resulted in a highly nonlinear model:

$$
\mathrm{CF}=13 \mathrm{C}^{-0.32}
$$

Because of the importance of the factors described in this section (e.g. inter-specific differences), it may not be appropriate to pool data for different species of fish. 
Other studies also suggest that use of a single concentration factor over a range of water concentrations is not appropriate. In the studies by Swanson $(1983,1985)$, the concentration factor for radium in several species of fish generally decreased with an increase in water concentration.

\section{CONCENTRATION FACTORS REPORTED FOR MARINE ORGANISMS}

Radium concentration factors for marine organisms were reported in a only a few published studies. These studies are reviewed here.

\section{Fish}

Table 4 presents concentration factors for $\mathrm{Ra}-226$ and $\mathrm{Ra}-228$ in marine fish taken off the coast of India (Iyengar et al., 1980). The concentration factor for Ra-226 in muscle ranged from 55 to 130 , and from 65 to 610 in bone (water concentration: $0.0015 \mathrm{~Bq} / \mathrm{l} ; 0.04 \mathrm{pCi} / 1)$. Concentration factors for $\mathrm{Ra}-228$ ranged from 21 to 63 in muscle and from 98 to 700 in bone (water concentration: $0.0119 \mathrm{~Bq} / \mathrm{l} ; 0.32 \mathrm{pCi} / \mathrm{l}$ ). The concentration factors were generally higher for Ra-226 than Ra-228 which had a higher concentration in water.

Table 4. Concentration factors for Ra-226 and Ra-228 in marine fish (India). ${ }^{1}$

\begin{tabular}{|c|c|c|c|c|c|}
\hline Species & Portion & $\begin{array}{l}\mathrm{Ra}-226 \\
\text { Water } \\
\mathrm{Bq} / \mathrm{l}(\mathrm{pCi} / \mathrm{l})\end{array}$ & $\mathrm{CF}$ & $\begin{array}{l}\text { Ra-228 } \\
\text { Water } \\
\mathrm{Bq} / \mathrm{l}(\mathrm{pCi} / \mathrm{l})\end{array}$ & $\mathrm{CF}$ \\
\hline sole & $\begin{array}{l}\text { muscle } \\
\text { bone }\end{array}$ & $\begin{array}{l}0.0015(0.04) \\
0.0015(0.04)\end{array}$ & $\begin{array}{c}55 \\
370\end{array}$ & $\begin{array}{l}0.0119(0.32) \\
0.0119(0.32)\end{array}$ & $\begin{array}{c}21 \\
160\end{array}$ \\
\hline mackerel & $\begin{array}{l}\text { muscle } \\
\text { bone }\end{array}$ & $\begin{array}{l}0.0015(0.04) \\
0.0015(0.04)\end{array}$ & 120 & $\begin{array}{l}0.0119(0.32) \\
0.0119(0.32)\end{array}$ & $\begin{array}{r}63 \\
700\end{array}$ \\
\hline ray & $\begin{array}{l}\text { muscle } \\
\text { bone } \\
\text { liver }\end{array}$ & $\begin{array}{l}0.0015(0.04) \\
0.0015(0.04) \\
0.0015(0.04)\end{array}$ & $\begin{array}{l}60 \\
65 \\
.\end{array}$ & $\begin{array}{l}0.0019(0.32) \\
0.0019(0.32) \\
0.0019(0.32)\end{array}$ & $\begin{array}{l}- \\
98\end{array}$ \\
\hline $\begin{array}{l}\text { oil } \\
\text { sardine }\end{array}$ & $\begin{array}{l}\text { muscle } \\
\text { bone }\end{array}$ & $\begin{array}{l}0.0015(0.04) \\
0.0015(0.04)\end{array}$ & $\begin{array}{l}130 \\
610\end{array}$ & $\begin{array}{l}0.0019(0.32) \\
0.0019(0.32)\end{array}$ & $\begin{array}{c}44 \\
180\end{array}$ \\
\hline range & $\begin{array}{l}\text { muscle } \\
\text { bone }\end{array}$ & & $\begin{array}{l}55 . \\
65 .\end{array}$ & & $\begin{array}{l}21 \cdot 63 \\
98-700\end{array}$ \\
\hline
\end{tabular}

1 from Iyengar et al., 1980

\section{Molluscs and Crustaceans}

Concentration factors for Ra-226 in marine molluscs were published by Iyengar (1984). The range of concentration factors in these animals was small (Table 5). The concentration factor for $\mathrm{Ra}-226$ in the soft parts of the molluscs ranged from 44 to 50 , and in the shell from 156 to 500 (water concentration: $0.0056-0.016 \mathrm{~Bq} / \mathrm{l} ; 0.15-0.4$ $\mathrm{pCi} / \mathrm{l})$.

Table 6 presents concentration factors for both $\mathrm{Ra}-226$ and $\mathrm{Ra}-228$ in marine molluscs (Iyengar et al., 1980). The concentration factor for Ra-226 in the soft parts of the shellfish ranged from 73 to 140 . The concentration factor for $\mathrm{Ra}-228$ ranged from 130 to 170 . 
Table 5. Concentration factors in marine molluscs (India). ${ }^{1}$

\begin{tabular}{|c|c|c|c|c|}
\hline Species & $\begin{array}{l}\text { Organ/ } \\
\text { body part }\end{array}$ & $\begin{array}{l}\text { Conc in } \\
\mathrm{Bq} / \mathrm{l}\end{array}$ & $\begin{array}{l}\text { water } \\
(\mathrm{pCi} / \mathrm{l})\end{array}$ & $\mathrm{CF}$ \\
\hline $\begin{array}{l}\text { oyster } \\
\text { (Ostrea sp.) }\end{array}$ & $\begin{array}{l}\text { soft parts } \\
\text { shell }\end{array}$ & $\begin{array}{l}0.0016 \\
0.0016\end{array}$ & $\begin{array}{l}(0.043) \\
(0.043)\end{array}$ & $\begin{array}{c}50 \\
500\end{array}$ \\
\hline $\begin{array}{l}\text { green mussel } \\
\text { (Perna viridis) }\end{array}$ & $\begin{array}{l}\text { soft parts } \\
\text { shell }\end{array}$ & $\begin{array}{l}0.0016 \\
0.0016\end{array}$ & $\begin{array}{l}(0.043) \\
(0.043)\end{array}$ & $\begin{array}{r}46 \\
419\end{array}$ \\
\hline $\begin{array}{l}\text { clam } \\
\text { (Meretrix sp.) }\end{array}$ & $\begin{array}{l}\text { soft parts } \\
\text { shell }\end{array}$ & $\begin{array}{l}0.0016 \\
0.0016\end{array}$ & $\begin{array}{l}(0.043) \\
(0.043)\end{array}$ & 200 \\
\hline $\begin{array}{l}\text { snail } \\
\text { (Thais sp.) }\end{array}$ & $\begin{array}{l}\text { soft parts } \\
\text { shell }\end{array}$ & $\begin{array}{l}0.0056 \\
0.0056\end{array}$ & $\begin{array}{l}(0.15) \\
(0.15)\end{array}$ & $\begin{array}{c}63 \\
156\end{array}$ \\
\hline $\begin{array}{l}\text { snail } \\
\text { (Petalla radiate) }\end{array}$ & $\begin{array}{l}\text { soft parts } \\
\text { shell }\end{array}$ & $\begin{array}{l}0.0016 \\
0.0016\end{array}$ & $\begin{array}{l}(0.043) \\
(0.043)\end{array}$ & $\begin{array}{l}44 \\
256\end{array}$ \\
\hline
\end{tabular}

1 from Iyengar, 1984

Table 6. Concentration factors for Ra-226 and Ra-228 in marine molluscs (India). ${ }^{1}$

\begin{tabular}{llllll}
\hline Species & Portion & $\begin{array}{l}\text { Ra-226 } \\
\text { Water } \\
\mathrm{Bq} / \mathrm{l}(\mathrm{pCi} / \mathrm{l})\end{array}$ & $\mathrm{CF}$ & $\begin{array}{l}\text { Ra-228 } \\
\text { Water } \\
\mathrm{Bq} / \mathrm{l}(\mathrm{pCi} / \mathrm{l})\end{array}$ & $\mathrm{CF}$ \\
\hline \multirow{2}{*}{ clam } & soft parts & $0.0015(0.04)$ & 140 & $0.0119(0.32)$ & 170 \\
\multirow{2}{*}{ oyster } & $\begin{array}{llllll} \\
\text { soft parts } \\
\text { shell }\end{array}$ & $0.0015(0.04)$ & 73 & $0.0119(0.32)$ & 130 \\
& $0.0015(0.04)$ & -- & $0.0119(0.32)$ & 100 \\
\hline
\end{tabular}

1 from lyengar et al., 1980

Marine crustaceans were also studied by Iyengar et al. (1980). For Ra-226 the concentration factor in the muscle of crustaceans ranged from 80 to 210 , and in the exoskeleton from 220 to 830 (Table 7). The range for Ra-228 was from 35 to 360 in muscle and from 230 to 800 in exoskeleton. Table 8 summarizes the range of concentration factors for marine molluscs and crustaceans in the reviewed literature.

\section{GENERIC CONCENTRATION FACTORS}

Generic or average values for concentration factors were suggested based on surveys of published data (Thompson et al. 1972, Cherry and Shannon 1974, IAEA 1982). Generic factors are meant for use in radiological assessment models for estimating the dose to man from a number of pathways. Commonly used models contain default concentration factors for a number of radionuclides and groups of organisms. The generic factors suggested by IAEA (1982) are used by many authors and models and are given in Table 9. IAEA (1985) revised these estimates upward for molluscs and fish (Table 9). 
Table 7. Concentration factors for Ra-226 and Ra-228 in marine crustaceans (India).

\begin{tabular}{lllclc}
\hline Species & Portion & $\begin{array}{l}\text { Ra-226 } \\
\text { Water } \\
\text { Bq/l (pCi/l) }\end{array}$ & CF & $\begin{array}{l}\text { Ra-228 } \\
\text { Water } \\
\mathrm{Bq} / l(\mathrm{pCi} / \mathrm{l})\end{array}$ & $\mathrm{CF}$ \\
\hline (iab & muscle & $0.0015(0.04)$ & 110 & $0.0119(0.32)$ & 180 \\
(Scylla serrata) $)$ & gills & $0.0015(0.04)$ & 340 & $0.0119(0.32)$ & 160 \\
crab & muscle & $0.0015(0.04)$ & - & $0.0019(0.32)$ & 35 \\
(Neptanus sp.) & gills & $0.0015(0.04)$ & 11000 & $0.0019(0.32)$ & 12000 \\
& exoskel & $0.0015(0.04)$ & 830 & $0.0019(0.32)$ & 800 \\
mole crab & muscle & $0.0015(0.04)$ & 210 & $0.0019(0.32)$ & 68 \\
& exoskel & $0.0015(0.04)$ & 220 & $0.0019(0.32)$ & 230 \\
prawn & muscle & $0.0015(0.04)$ & 80 & $0.0019(0.32)$ & 360 \\
& muscle & $0.0015(0.04)$ & - & $0.0019(0.32)$ & 56 \\
& exoskel & $0.0015(0.04)$ & 360 & $0.0019(0.32)$ & 300 \\
\hline
\end{tabular}

1 from lyengar et al., 1980.

Table 8. Molluscs and crustaceans - ranges of concentration factors in the reviewed literature.

\begin{tabular}{llll}
\hline & $\begin{array}{l}\text { Water } \\
\mathrm{Bq} / \mathrm{l}(\mathrm{pCi} / \mathrm{l})\end{array}$ & $\begin{array}{l}\text { Soft Parts/ } \\
\text { Muscle }\end{array}$ & $\begin{array}{l}\text { Shell/ } \\
\text { Exoskeleton }\end{array}$ \\
\hline $\begin{array}{l}\text { Molluscs - Marine } \\
\text { (Ra-226) }\end{array}$ & $0.016(0.43)$ & $44-63$ & $156-500$ \\
$\begin{array}{l}\text { Molluscs - Marine } \\
\text { (Ra-226) }\end{array}$ & $0.0015(0.04)$ & $73-140$ & $\cdots$ \\
$\begin{array}{l}\text { Molluscs - Marine } \\
\text { (Ra-228) }\end{array}$ & $0.0119(0.32)$ & $130-170$ & 100 \\
$\begin{array}{l}\text { Crustaceans - Marine } \\
\text { (Ra-226) }\end{array}$ & $0.0015(0.04)$ & $80-210$ & $220-830$ \\
$\begin{array}{l}\text { Crustaceans - Marine } \\
\text { (Ra-228) }\end{array}$ & $0.0119(0.32)$ & $35-360$ & $230-800$ \\
& & & $100-500$ \\
Molluscs - Overail Range & $\begin{array}{l}0.0015-0.016 \\
(0.04-0.43)\end{array}$ & $44-170$ & $220-830$ \\
Crustaceans - Overall Range & $\begin{array}{l}0.0015-0.0119 \\
(0.04-0.32)\end{array}$ & $35-360$ & \\
\hline
\end{tabular}

1 Iyengar,1984

2 lyengar et al., 1984 
Table 9. IAEA generic concentration factors for radium.

IAEA (1982) IAEA (1985)

$\begin{array}{lll}\text { Marine Fish } & 100 & 500\end{array}$

$\begin{array}{lll}\text { Marine Invertebrates } & 100 & 1000\end{array}$

$\begin{array}{lll}\text { Marine Crustaceans } & 100 & 100\end{array}$

Site and species specific concentration factors are not usually available, and developing them for a specific site is expensive and time consuming. The variation within and between species, and the many other variables which can affect the concentration factor make using generic factors problematic, but also, in most cases, necessary. In a preliminary risk assessment study the use of generic factors is appropriate. If the resulting estimates are high compared to background or to an acceptable level of risk, detailed site specific data will be needed.

\section{CONCENTRATION FACTORS DERIVED FROM A FIELD STUDY IN COASTAL LOUISIANA}

Data collected included Ra-226 and Ra-228 concentrations in water, sediment, fish, shellfish and crustaceans at three produced water outfalls and three background stations in Louisiana (CSA, 1991). The three outfalls were located in canals along the Louisiana coast. Concentrations of Ra-226 and Ra-228 in the discharges were 228.9 and $383.0 \mathrm{pCi} / \mathrm{l}$ for outfall $1,110.6$ and $244.4 \mathrm{pCi} / \mathrm{l}$ for outfall 2 , and 251.9 and 254.9 $\mathrm{pCi} / 1$ for outfall 3 .

Radium concentrations were measured in water and sediment at stations located 25 and 50 feet from the outfalls, in three directions (the outfalls were located along one side of a canal). Biological samples were taken within 50 feet of the discharge point. All mollusc samples were oyster (Crassostrea virginica), and all fish samples were seatrout (Cynoscion sp.). Crustaceans sampled at Site 2 were crabs (Callinectes sp.) and at Sites 1 and 3 were shrimp (Penaeus sp.). Oysters were removed from the shell before analysis. Fish and crustacean samples were whole-body samples, including bone, skin and exoskeleton.

Concentration factors were calculated for each site/organism combination as follows:

$$
\begin{aligned}
& \text { Concentration } \\
& \text { Factor }
\end{aligned} \frac{\text { concentration in organism }(\mathrm{pCi} / \mathrm{g}) \times 1000(\mathrm{~g} / \mathrm{l})}{\text { concentration in water }(\mathrm{pCi} / \mathrm{l})}
$$

Table 10 gives the concentration data and concentration factors for Ra-226 and Ra228 at the three sites and the six background reference stations. The concentration factor was calculated for the water concentration at 50 feet from the outfall. Because the biological samples were taken within (not at) 50 feet of the discharge, these values represent maximum concentration factors. The values reported here are also uncertain because concentrations at or below the detection limit for the analytical system used were reported as zeros, underestimating the concentration of radium in water, and overestimating the concentration factor. Because water samples were not taken exactly at the locations where biological samples were harvested, the data set does not provide enough data to develop a model for the concentration factor of radium based on water concentrations. 
Table 10. Calculated radium concentration factors ${ }^{1}$ for organisms sampled in the CSA (1991) study.

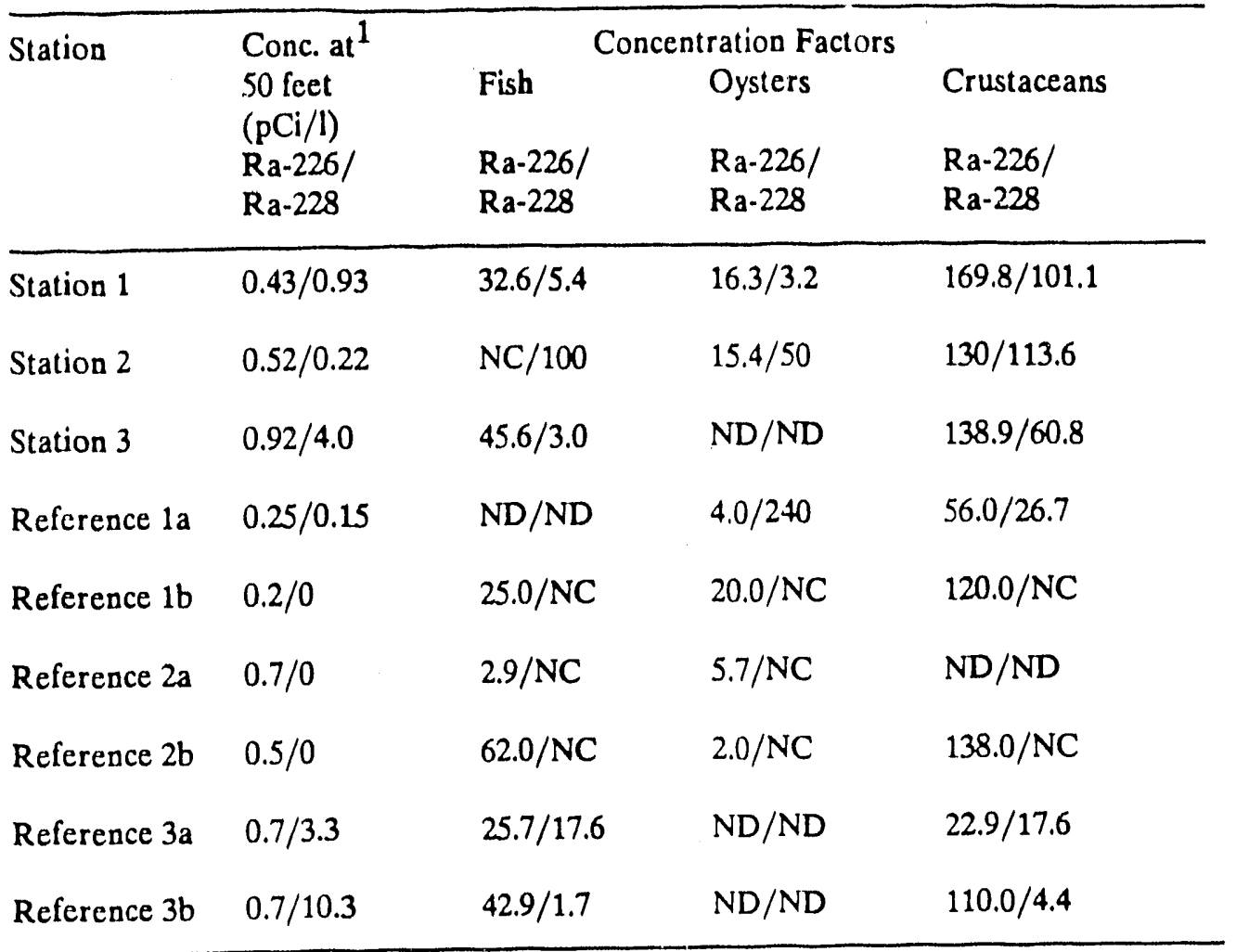

ND: no data

NC: concentration factor not calculated because water or animal concentration was reported in CSA (1991) as 0.

1 average of measured concentration at three stations, each 50 feet from discharge.

The calculated concentration factors based on this data set cover a wide range. Figure 1 shows the ranges of concentration factors for whole fish (seatrout), the soft parts of molluscs (oysters), and whole crustaceans (crabs and shrimp). Concentration factors ranged from 1.7 to 100 for whole fish, from 2 to 240 for the soft parts of molluscs and from 4.4 to 169.8 for whole crustaceans.

The concentration factors calculated from the CSA data set (1991) were used to derive a distribution of concentration factors, including a mean or expected value and a $95 \%$ confidence value for whole fish, the soft parts of molluscs and whole crustaceans. A latin hypercube sampling process was used to generate a distribution of concentration factors, by sampling the available data 5000 times.

Table 11 gives the expected value, and $95 \%$ confidence limit for fish, molluscs and crustaceans generated in this analysis. Figure 2 gives the cumulative distribution of concentration factors for fish, molluscs and crustaceans. 


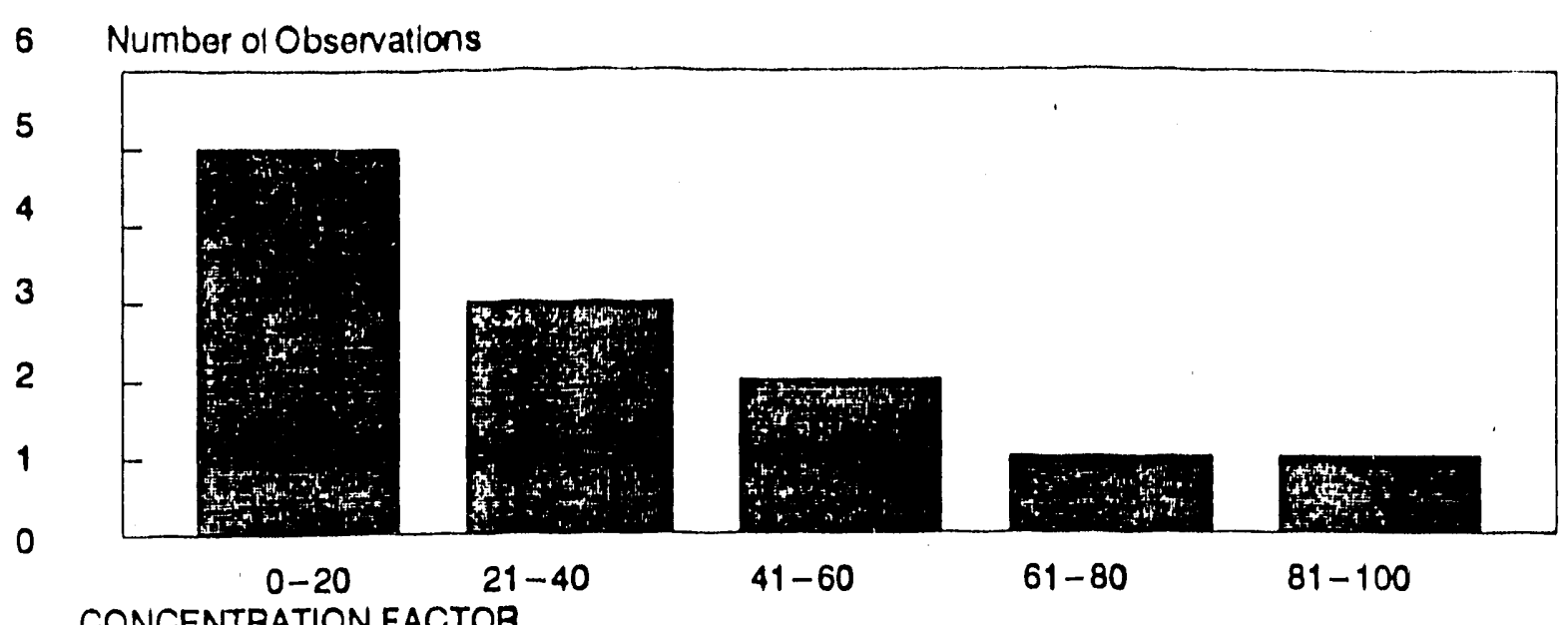

CONCENTRATION FACTOR

\section{FISH}

Number of Observations

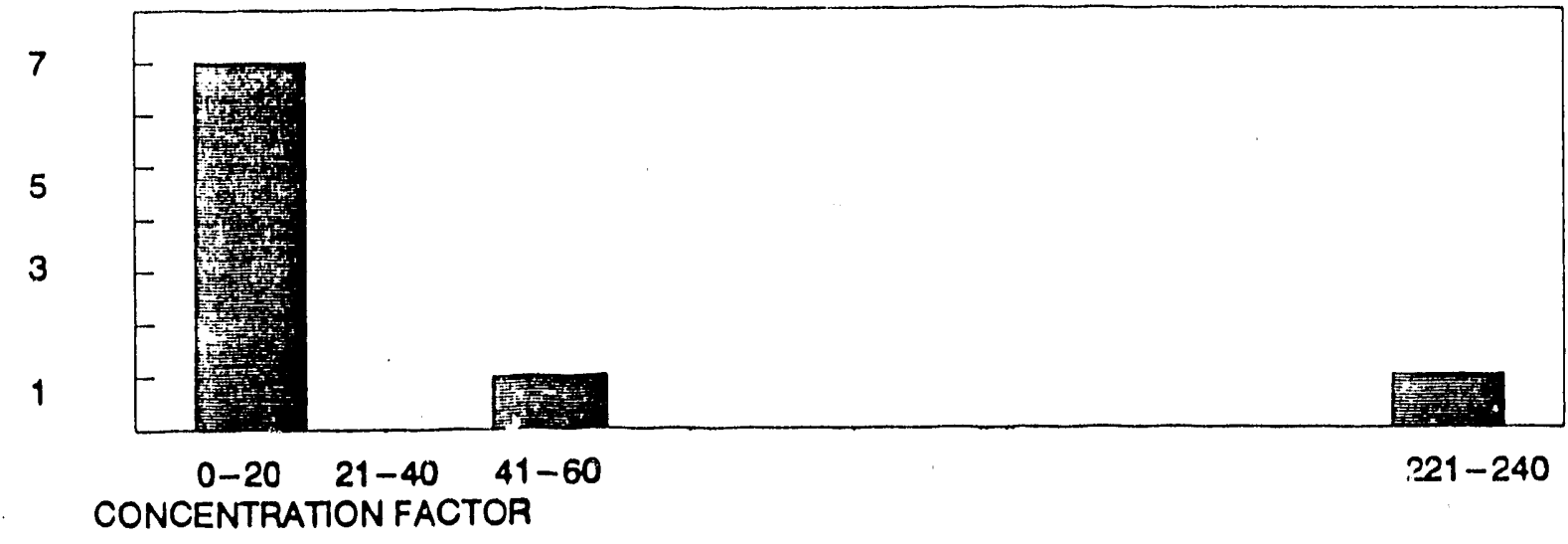

MOLLUSCS

Number of Observations

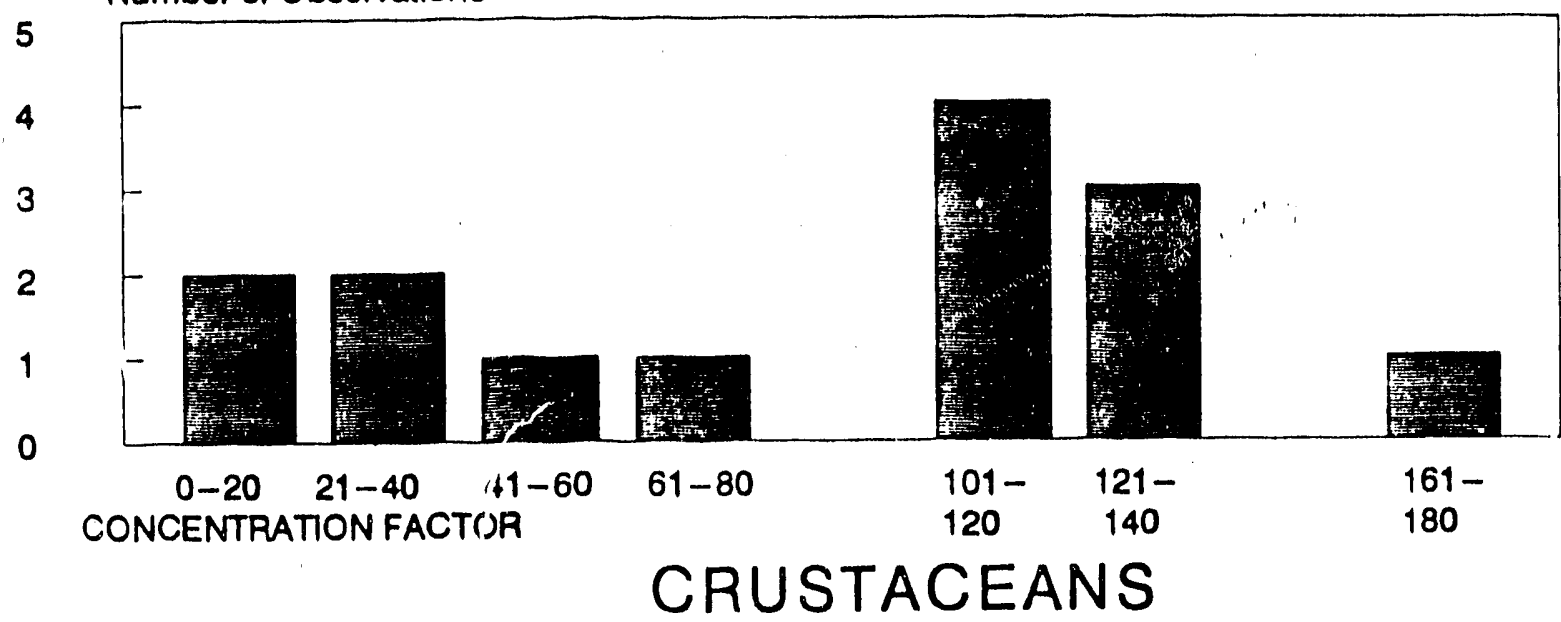

Figure 1. Distribution of calculated concentration factors for whole fish, the soft parts of molluscs and whole crustaceans sampled in coastal Louisiana. 

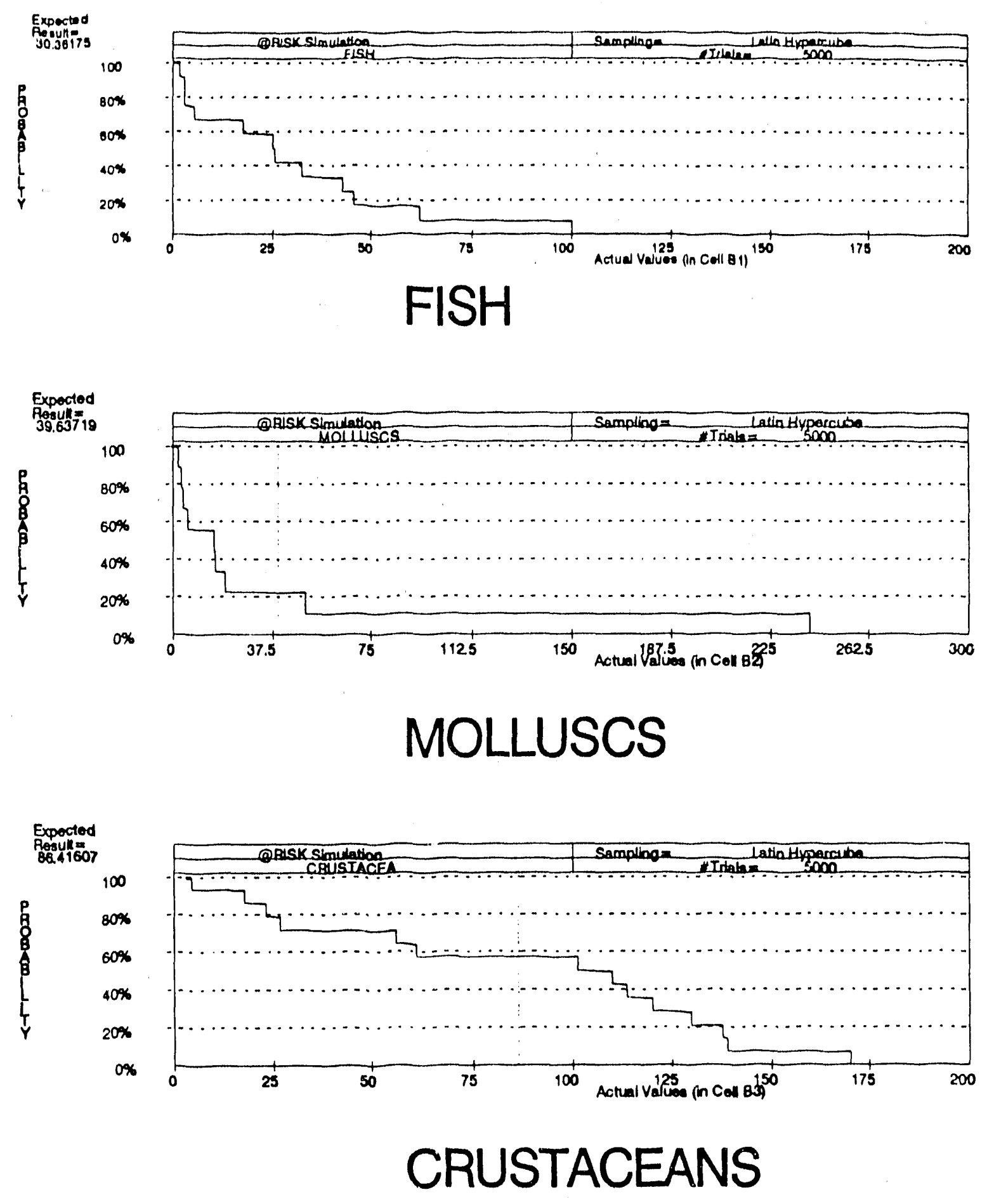

Figure 2. Generated cumulative distribution of concentration factors for whole fish, the soft parts of molluscs and whole crustaceans sampled in coastal Louisiana. 
Table 11. Expected value and $95 \%$ confidence interval for simulated distributions of the concentration factor.

\begin{tabular}{lcc}
\hline Organism Type & Expected value & 95\% Confidence Interval \\
\hline Whole Fish & 30.4 & 100 \\
Molluscs soft parts & 39.6 & 240 \\
Whole crustaceans & 86.4 & 170 \\
\hline
\end{tabular}

\section{SUMMARY AND DISCUSSION}

The generic concentration factors suggested by IAEA (1982) (100 for marine fish, molluscs and crustaceans) are consistent with the high values reported in the literature (Table 4, Table 8). The higher values suggested in IAEA (1985) (Table 9) are not supported by these data.

An analysis of data collected in coastal Louisiana suggests an average or expected value of 30.4 for whole fish, 39.6 for the edible parts of molluscs and 86.4 for whole crustaceans would be applicable concentration factors for radium discharged in produced waters to the Gulf Coast. The concentration factors calculated from this data set are uncertain, because of a problem with values near the detection limit, and because animals were not sampled exactly at stations sampled for water radium concentrations. These data also overestimate the concentration factors for the edible parts of fish and crustaceans because they were based on whole animal samples.

The concentration factor for radium is a critical value in a risk assessment study of the health and environmental effects of radium in coastal and offshore environments. Additional data are needed to describe better the distribution of radium concentration factors in the edible portions of animals used for food. Generic concentration factors are appropriate for use only in a screening-level assessment.

\section{REFERENCES}

CSA, 1991, "Measurements of Naturally Occurring Radioactive Materials (NORM) at Three Produced Water Outfalls", Continental Shelf Associates, Inc., Jupiter, Florida, prepared for Mid-Continent Oil and Gas Association, Baton Rouge, Louisiana.

de Bortoli, M., and Gaglione, P., 1972, Ra-226 in environmental materia.is and foods. Health Physics. 22:43.

Duke, T., Willis, J., Price T., and Fischler, K., 1969, Influence of environmental Factors on the concentration of $\mathrm{Zn}-65$ by an experimental community, in: "Symposium on Radioecology", Proc. Second National Symposium, Ann Arbor Michigan, May 1967, D.J. Nelson and F.C. Evans, eds, CONF-670503, March 1969, United States Atomic Energy Agency, Washington, D.C.

IAEA, 1982, "Generic Models and Parameters for Assessing the Environmental Transfer of Radionuclides from Routine Releases", Safety Series No. 57. Procedures and Data. International Atomic Energy Agency, Vienna.

IAEA, 1985, "Sediment $K_{d}$ s and Concentration Factors for Radionuclides in the Marine Environment", Technical Report s Series No. 247, International Atomic Energy Agency, Vienna.

Iyengar, M.A.R., 1984, Distribution in nature, in: "The Behavior of Radium in Waterways and Aquifers", IAEA-TEC DOC 301. International Atomic Energy Agency, Vienna. 
Iyengar, M.A.R., Rajan, M.P., Ganapathy, S. and Kamath, P.R., 1980, Sources of radiation exposure in a low monazite environment, in: " The Natural Radiation Environiment III", Symp. Proc. Houston, 1978, CONF-780422. Technical Information Center, Springfield pp. 1090-1106.

Snavely, E.S. Jr., 1989, "Radionuclides in Produced Water", Production Department, American Petroleum Institute, Washington, D.C.

Swanson, S.M., 1985, Food chain transfer of U. ueries radionuclides in a northern Saskatchewan aquatic system, Health Physics. 49:747.

Swanson, S.M., 1983, Levels of Ra226, Pb210 and total uranium in fish near a Saskatchewan uranium mine and mill, Health Physics. 45:67.

Thompson, S.E., Burton, C.A., Quinn, D.J., and Ng, Y.C., 1972. "Concentration Factors of Chemical Elements in Edible Aquatic Organisms", Lawrence Livermore National Laboratory, University of California, Report UCRL-50564, Revision 1.

Till, J.E. and Meyer, H.R., 198j, "Radiological Assessment: A Textbook on Environmerital Risk Analysis", NUREG/CR-3332, ORNL-5968, U.S. Nuclear Regulatory Commission, Washington, D.C.

Williams, A.R., 1984, Biological uptake and Transport, in: "The Behavior of Radium in Waterways and Aquifers", IAEA-TEC DOC 301, International Atomic Energy Agency, Vienna.

\section{DISCLAIMER}

prepared as an account of work sponsored by an agency of the United States inted States Gnernment nor any agency thereof, nor any of their Government. Neither the United Stapress or implied, or assumes any legal liability or responsiemployees, makes any warranty, express or implied, of any information, apparatus, product, or bility for the accuracy, completeness, or usefulness of any inforinge privately owned rights. Referprocess disclosed, or represents that its use would nocess, or service by trade name, trademark, ence herein to any snecific commercial product, process, or service by its endorsement, recommanufacturer, or otherwise does not necessarily constitute or imply its ency thereof. The views mendation, or favoring by the United States Government or any state or reflect those of the and opinions of authors expressed herein do not

United States Government or any agciniy the:eof 

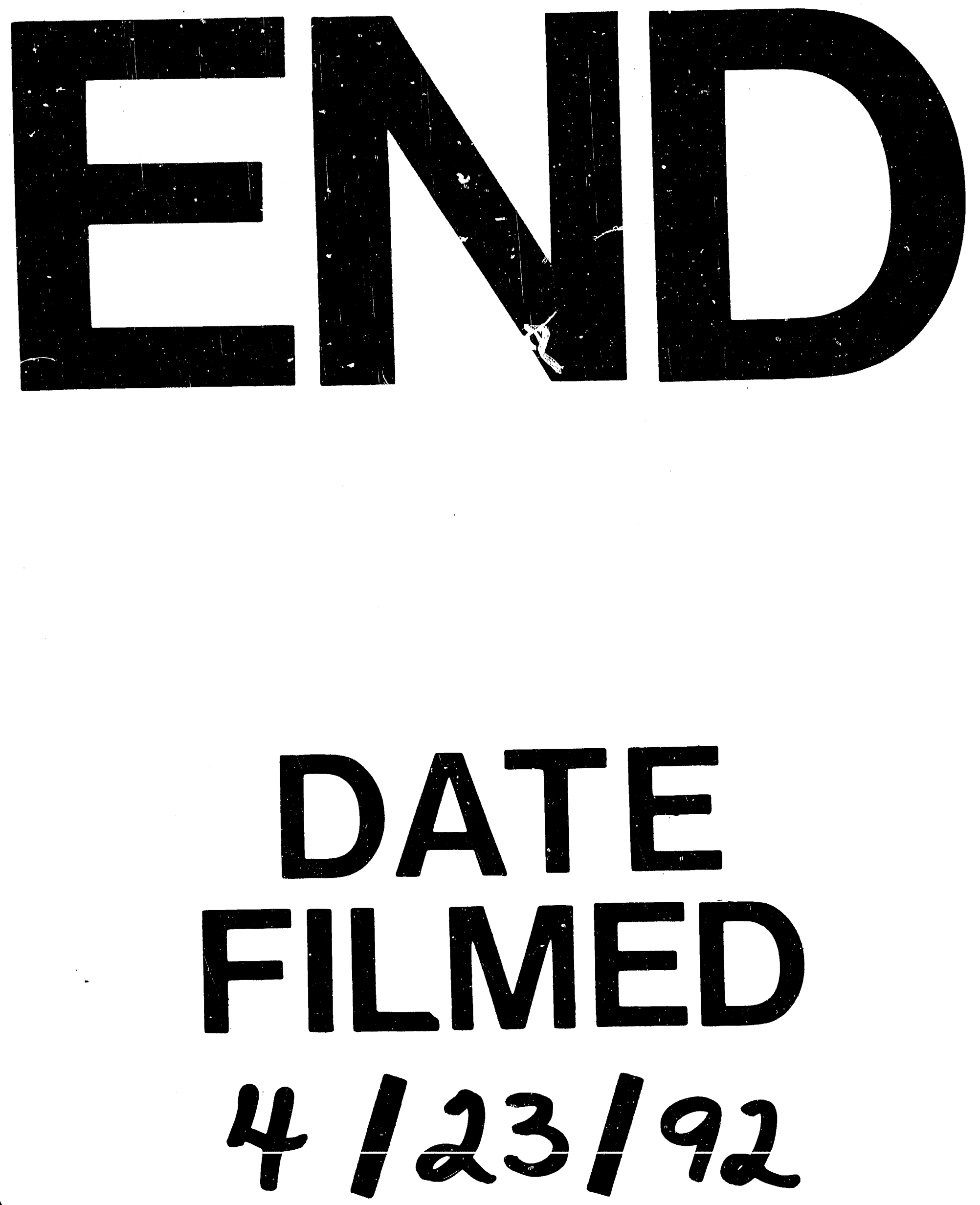
